Max-Planck-Institut für demografische Forschung

Max Planck Institute for Demographic Research

Konrad-Zuse-Strasse 1 - D-18057 Rostock - GERMANY

Tel +49 (0) 3812081 - 0; Fax +49 (0) 3812081 - 202;

http://www.demogr.mpg.de

MPIDR WORKING PAPER WP 2003-007

FEBRUARY 2003

\title{
Developing Country \\ Growth Collapse Revisited: \\ Demographic Influences and \\ Regional Differences
}

Brant Liddle (btliddle@alum.mit.edu)

This working paper has been approved for release by: Alexia Fürnkranz-Prskawetz

(fuernkranz@demogr.mpg.de), Head of the Research Group on Population, Economy, and Environment.

(C) Copyright is held by the authors.

Working papers of the Max Planck Institute for Demographic Research receive only limited review.

Views or opinions expressed in working papers are attributable to the authors and do not necessarily reflect those of the Institute. 
Developing Country Growth Collapse Revisited: Demographic Influences and Regional Differences

\section{Brant Liddle}

Max Plank Institute for Demographic Research

Konrad-Zuse-Str. 1

18057 Rostock, Germany

phone: +49 (0) 3812081175

fax: $\quad+49(0) 3812081475 \& 1-603-908-6573$

btliddle@alum.mit.edu 
Developing Country Growth Collapse Revisited: Demographic Influences and Regional Differences

\begin{abstract}
This paper bridges two related, but up to now, unconnected literatures: economic growth stability and population-economic growth. The paper is different from previous populationeconomic growth analyses by focusing on instability of economic growth in developing countries. This study contributes to a previous paper on the developing country growth collapse by adding important demographic variables. The paper provides an explanation for "new" negative correlations of population and economic growth: because 1960s were a relatively smooth time for economic growth, youth dependency did not seem important; however, during turbulent 1970s and 1980s, countries with falling dependency burdens weathered economic shocks better.
\end{abstract}

Keywords: economic growth, population growth, demographic transition, developing countries, instability of economic growth

JEL classification: $\mathrm{O} 1, \mathrm{O} 4, \mathrm{~J} 10$ 


\section{Introduction}

An important purpose of this paper is to bridge two highly related, but up to now, rather unconnected literatures: the economic growth stability literature and the population and economic growth literature. Essentially, I combine a left-hand-side variable from the former literature with some of the right-hand-side variables of the latter. By providing a link between these two literatures, the paper also seeks to shed light on two emerging puzzles from these literatures: (1) why did some countries' growth collapse sometime during the 1970's, and others' did not; and (2) why did population growth have a negligible-to-no effect on economic growth during the 1960s and 1970s, but have a negative impact in the 1980s.

In this paper I follow a research strategy recommended by Pritchett (2000): to analyze the determinants of changes in growth rates. Specifically, I examine how population may impact countries' abilities to withstand external shocks, and thus help explain the volatility of developing countries' growth, particularly in the last two decades. This paper is most like Rodrik (1999), who argued that the presence of domestic social conflict and the institutions in place to deal with those conflicts impact how countries react to external shocks. He examined the change in per capita GDP growth over two periods 1960-1975 and 1975-1989, and various measures of shocks, internal division, and institutions of conflict management. He found that existence of social consensus and working conflict management institutions lead to greater persistence of economic growth. The social conflict-management institutions hypothesis was determined to be robust when considering alternative explanations for the growth collapse. Indeed, explanations like "more open trade regimes avoided trouble," "large public sectors were worse-hit," or "high indebtedness in the 1970s led to trouble" added little explanatory power.

The only population variable Rodrik used, however, is a measure of ethnolinguistic fractionalization, which comes from Taylor and Hudson (1972). This variable is constructed 
from a 1960 USSR study, and measures the probability that two randomly selected persons from a given country will not belong to the same ethnolinguistic group. The rationale for including this variable, used by others in growth analyses (e.g., Mauro, 1995, Easterly and Levine, 1997, and Kenny, 1999), typically is that countries with more divided societies will either have greater internal conflict or more difficulty implementing policies. But the study reported here indicates that another population variable — youth dependency — has a significant bearing on how external shocks impact economic growth. Yet, the populationeconomic growth literature has focused on youth dependency's impact on the level of economic growth, not focused as this paper is on the determinants of changes in economic growth, and the basic finding of that literature can be summarized as: youth dependency had an insignificant impact on economic growth in the 1960s and 1970s, but had a "negative, statistically significant, and large" impact in the 1980s (Kelley and Schmidt, 2001).

\section{Background}

Much of the early work on population growth and per capita income growth found little relationship between the two. Indeed, Kelley and Schmidt (1995) claimed the most important finding of the literature up to that point, “. . is the failure, in more than a dozen studies using cross-country data, to unearth a statistically significant association between growth rates of population and of per capita output." This earlier work typically examined only aggregate population growth rates.

More recent work has either decomposed population growth into fertility and mortality components or considered the growth rates of important sub-populations (e.g., school-aged, working-aged, retired). These studies (Barlow 1994, Bloom and Freeman 1988, Brander and Dowrick 1994, Kelley and Schmidt 1995, Crenshaw et al. 1997, and Bloom and Williamson 1998) found a more complex role for population. Specifically, they found (depending on their exact explanatory variables) either that growth of the working-aged 
population is good for economic growth while growth of young, dependant population is not; or that increases in fertility or births have an immediate, negative impact, although the resulting eventual increase in the economically active population will have a delayed, positive impact. Thus, the demographic transition - the change from high to low rates of mortality and fertility_produces a "demographic gift" (Bloom and Williamson 1998), "demographic windfall" (Crenshaw et al. 1997), or "window of opportunity" (Barlow 1994). The studies that break variables down according to time periods in their analyses (Bloom and Freeman 1988, Brander and Dowrick 1994, and Kelley and Schmidt 1995) found a stronger negative correlation between population growth and economic growth in the 1980s. This "new" negative correlation has not been fully explained (although Kelly and Schmidt 1995, unlike the others, do offer an explanation).

The developing country growth collapse-i.e., that growth in developing countries was much lower in the second half of the 1970s and in the 1980s and 1990s than in the 1960s or in the first part of the 1970s_-is now well documented. Easterly (2001) calculated that the median per capita income growth rate in developing countries fell from 2.5 percent over 1960-79 to 0.0 percent over 1980-98. For the sample of 94 developing countries I consider, the average per capita GDP growth rate fell from 2.5 percent over 1960-75 to 0.7 percent during 1975-1992. Pritchett (2000) calculated a single break point (or year) in each country's growth from 1960 to 1992 (or to the most recent year with data). For the 87 developing countries in his sample, only 24 had growth rates of less than 1.5 percent per year prior to their break year. However, after their break year only 26 countries had growth rates over 1.5 percent, and 32 had negative growth rates post-break. In a similar study, Ben-David and Papell (1998) calculated specific year break points in growth that are statistically significant for countries between 1950 and 1990. Twenty-one developing countries in their sample (which includes a total of 37 developing countries) had negative growth after their break 
point. (For the countries with negative post-break growth, those break years ranged from 1972-1983.)

This collapse of growth is not, however, easy to explain by changes in what are widely regarded as determinants of growth. According to Easterly (2001), indicators like educational enrollment, infrastructure, life expectancy, fertility, inequality, and real exchange overvaluation showed improvement over the 1980s and 1990s, while black market premiums, inflation, and openness failed to show the kind of deterioration that could explain the growth decline. Indeed, Easterly argued that, if models of growth using these indicators and policies were correct, developing country growth rates should have been significantly higher during the 1980s and 1990s than in the previous decades. Furthermore, external shocks (like wars, the oil crises, or the economic slowdown in the developed countries) can only explain some of the variation in growth during the 1970s and 1980s (Easterly et al., 1993 and Rodrik, 1999). For example, many of the high-growth, East Asian countries experienced external shocks at least as strong as those encountered in Latin America. Rodrik (1999) argued that variation in investment can not drive the variation in growth rates over short horizons, since investment rates are persistent over time-investment in one period is very strongly correlated with investment in the subsequent period. Thus, it seems GDP growth, particularly in developing countries, became much harder to achieve in the period beginning sometime during the 1970s. This study is different from previous population-economic growth analyses in several important ways. First, rather than try to explain economic growth by assuming it is persistent (which the previously discussed economic growth literature shows it is not), I focus on explaining the important finding of the volatility/instability of economic growth in developing countries. Second, this paper suggests a new theory on how population may matter to economic growth (the old ways being through the size of the labor force and dependents' impact on investment and savings). That is, I hypothesize countries with large working 
populations relative to dependent ones may have more resilience to external shocks. This relationship could exist through the increased policy flexibility that having fewer dependants (and, thus, fewer "sticky" programs) may afford. Lastly, again by utilizing the recent findings on the instability of developing country growth, I calculate growth rates based on theoretically meaningful periods - rather than calculating a single rate spanning the available data set or using culturally appealing break points (i.e., the decades), as all previously mentioned population-economic growth studies did. These last two differences allow an explanation of the "new" population-economic correlation discussed above. In addition, like Bloom and Williamson (1998) and Crenshaw et al. (1997), I use the more theoretically appealing agespecific growth rates, rather than birth and death rates. Specifically, I use the rate of change of the youth dependency ratio, which equals the difference between the growth rates of the working aged population and the young, dependant population.

\section{Methodology and Data}

Following Rodrik (1999), I divide the sample into two periods, 1960-1975 and 19751990. (Actually, I use 1992 or the most recent year for which there is GDP data. The specific countries used and their last year of GDP data is contained in the appendix.) There are a number of reasons to support this disaggregation. Pritchett (2000) calculated a mean break year for developing countries of 1977 and a median of 1978. In addition, Rodrik (1999) ran his regressions by dividing the sample into two periods using both 1975 and Pritchett's individual country break years, and got very similar results.

I begin by running two sets of OLS regressions, each with a different dependent variable. The first regression uses the difference between growth in the second period and the sample average growth rate for the second period. In the second regression, the dependant variable is, as in Rodrik (1999), the growth differential between 1960 to 1975 and 1975 to 1992. I define all rates of change used in this paper as the natural log difference between the 
later data point and earlier one, divided by the number of intervening years. Rates of change are expressed in percentage terms. For GDP, I use the chain-linked index of real GDP per capita measured in 1985 purchasing power parity dollars from the Penn World Tables Mark 5.6a. All population data comes from the World Bank Development Indicators 2000 (with the one exception of Taiwan, for which the data comes from the Monthly Bulletin of Statistics of the Republic of China). In the first regression, I am interested in explaining why some countries did much better than others during the second period, given that nearly all countries did worse than they did in the first period. In the second regression, I am investigating the degree to which a country's growth changes over the two periods. As it turns out, the answers look much the same for both questions.

For independent variables I use: regional dummies for Latin America and the Caribbean, Asia, and sub-Saharan Africa (LAC, ASIA, and SSA, respectively); the natural log of per-capita GDP in 1975 (LNGDP75); lagged GDP growth; the youth dependency ratio (the population ages 0-14 over the population 15-64) in 1975 (YDEP75), and the rate of change in the youth dependency ratio from 1975-1990 (YOUTHDEPCHANGE). The countries included in the regional dummies conform to the standard World Bank definitions. The lagged GDP growth term is either the difference between average per-year growth during 1960-1975 and the sample average growth for that period, DIFAVG6075 (in the case of the first regression), or the average per-year GDP growth from 1960-1975, GDPGROWTH6075 (in the case of the second regression). In addition, I, like Rodrik, include ethnolinguistic fractionalization, ETHNICFRAC, and a measure of government effectiveness/quality, QUALTGOV9801.

The index for government effectiveness/quality I use comes from a set of aggregate measures by Kaufmann, Kraay, and Zoido-Lobaton (1999). They compile six different measures of governance, each measure made up of data from various sources, and assign 
countries values ranging from -2.5 to 2.5 for each measure for which a country has some data. The six aggregate measures are: voice and accountability; political instability and violence; government effectiveness; regulatory burden; rule of law; and graft. For each country I calculate the average over the various measures (not every country has a value for each of the six different measures), and over the two years for which they report data (1998 and 2001). I use their measures and take an average over the various measures so I can include in the regressions each country for which there is relevant population and GDP data. A popular government quality index (but containing fewer countries) —which was used, for example, in Easterly and Levine (1997) and Easterly and Kraay (2000), from the Institutional Investor Risk Ratings, collected over 1960-1998—correlates highly (0.7) with the measure I use. In addition, Rodrik (1999) argued that measures like Freedom House's democracy index are very stable over time (the correlation coefficient across decades is 0.9 ).

\section{Results: a first cut}

Before discussing the regression results, I shall show the data. Figure 1 indicates the first puzzle mentioned at the top of the paper, i.e., many countries had very different growth experiences in the period 1960-1975 than in 1975-1992. Furthermore, growth in the earlier period seems to have very little relationship to growth in the later period. Figures 2 and 3 provide some indication of the second puzzle - the changed relationship between population and economic growth in more recent years. Figure 2 shows no relationship between the average annual per capita GDP growth during 1960-1975 and the annual rate of change of the youth dependency ratio over that same period. However, Figure 3 shows a clear, negative relationship ( $\mathrm{R}^{2}$ of 0.3) during 1975-1990; that is, greater economic growth is correlated with a larger decline in youth dependency. 
Figures 1-3

The results of the first three regressions (using the two slightly different dependent variables described above) are shown in Tables 1 and 2. The independent variables have the expected signs and are, in general, highly statistically significant. Most important, ethnolinguistic fractionalization, quality of government, the change in youth dependency, and the level of youth dependency in 1975 are all significant and impact as would be expected; i.e., greater social division leads to greater susceptibility to external economic shocks (or lower growth in the later period), and a better quality of government and lower dependency burden (both change and level) lead to higher growth. Both the independent variable coefficients and their associated standard errors are essentially the same in the two regressions. The only exception is the variable for lagged economic growth. It is not statistically significant in the first regression (Table 1), where it represents the per capita GDP growth from 1960-1975 minus the sample average for that period. This fact is not surprising given the relationship displayed in Figure 1. In the second regression (Table 2), the one most similar to Rodrik's (1999), the coefficient, which represents per capita growth 1960-1975, is statistically significant (as it is for Rodrik's). Again, this finding is not surprising since the dependent variable is per capita growth over 1975-1992 minus per capita growth over 19601975.

Tables 1 and 2

Comparing the results shown in Table 2, Column 1 with the results from the two most similar of Rodrik's regressions (reported in Table 4, columns 5 and 6 of Rodrik), the magnitude, sign, and significance of most coefficients are quite similar to or the same as those in Rodrik's regressions. One difference is that my substituting the population dependency variables for Rodrik's measure of terms of trade shocks (a variable not significant in his regressions) seems to improve the explanatory power - an adjusted $R^{2}$ of 0.70 versus 0.62 and 
0.54 in Rodrik's study. It should be noted that Rodrik's measure of government is somewhat different; the other variables, however, are essentially the same. More interesting though is the Asia dummy variable. This variable is positive and significant in Rodrik's regressions, but not in either of mine. Rodrik claimed to be disappointed that the Asia dummy variable remained significant after the introduction of proxies for social conflict. It appears that youth dependency is the variable that needs to be added to describe Asia's experience in this turbulent time of economic growth (a fact probably not surprising to Bloom and Williamson, 1998).

The main motivation for the first formulation of the dependent variable (i.e., the difference between growth in the second period and the sample average growth rate for the second period) was to address statistical problems that might have arisen from the second formulation. In the second formulation of the dependent variable (i.e., the growth differential between 1960 to 1975 and 1975 to 1992 ), the regression contains income growth from 1960 to 1975 on both sides of the equation. However, in all the regressions run, like those shown in Table 1 and Table 2, Column 1, the results were essentially the same for both formulations (except that the lagged growth term was insignificant for the first formulation). Thus, for brevity and consistency with the Rodrik study, I report statistics only from the second formulation of the dependent variable (the growth differential) in all of the following tables.

In Table 2, Column 2 I examine whether trade impacts GDP growth stability. I include variables that measure openness to trade and the extent to which countries' trade relies on commodities. The variable, TRADEOPEN, is total trade-imports plus exports-in percent of GDP averaged over 1975-1990 (data from Global Development Finance and World Development Indicators). In order to determine whether a country's openness to trade made it susceptible to shocks over 1975-1990, it might seem reasonable to gather data over an earlier period, like 1970-1974 (which is what Rodrik did in his analysis of trade). I use the 1975- 
1990 data because using an earlier period would mean "loosing" countries from my data set (I loose only Iraq with the longer, more recent period), and the TRADEOPEN variable when calculated using the two different periods is highly correlated (0.94). In addition, this regression contains two dummy variables, EXPORTOIL and EXPORTPRIM, that measure the extent to which a country's trade depends on fuel (mostly oil) or nonfuel primary products (SITC 0, 1, 2, 4, and 68), respectively. These two variables have values of one if the export category described above accounts for 50 percent or more of the country's total exports in the period 1988-1992 (data from World Development Report 1995).

It seems reasonable, a priori, that countries heavily reliant on commodities would be susceptible to shocks (particularly of the energy induced variety). From Column 2, Table 2 it is clear openness to trade had nothing to do with the growth collapse (Rodrik, 1999, similarly finds three different trade variables statistically insignificant); however, the structure of exports (a variable not used by Rodrik) does have an impact. Countries heavily reliant on

primary (nonfuel) exports will be more likely to experience a growth collapse. The coefficient for oil exporters, although not statistically significant at a standard level (the probability associated with its t-statistic is 0.77 ), is positive. This surprising result (i.e., a positive coefficient) may be explained by the fact many major oil producers, like Saudi Arabia and Kuwait, were left out of the sample.

\section{Further investigation}

Initially, I believed the Sub-Saharan African or Asian countries would be the cause of any instability in the regression results. However, a series of Chow tests confirmed that the Latin American and Caribbean countries justified a structural change in the relationship. Table 3 shows the previous regression (displayed in Table 2, Column 2) run with the sample divided among Latin American and Caribbean countries (a total of 25) and all other countries in the original sample (68). The first half of the table indicates the results are robust for 
African, Mediterranean, and Asian countries_-all of the statistically significant dependent variables are still significant (with the exception of level of youth dependency). In addition, the adjusted $\mathrm{R}^{2}$ increased from 0.70 to 0.78 with the exclusion of the Latin American and Caribbean countries. On the other hand, for the regression run only with Latin American and Caribbean countries, the only variable that is at all significant is GDP growth over 1960-1975.

\section{Table 3}

\subsection{Latin American and Caribbean experience}

To further explore the difference in the development experience in the Western Hemisphere, I add a variable to measure terms of trade shock (Rodrik included a trade shock variable that is significant in about half of his regressions). This variable, TRADESHOCK, is the standard deviation over 1960-1995 of the growth in export deflator minus growth in import deflator, weighted by current LCU shares of exports and imports in GDP (it comes from Easterly and Kraay, 1999). In addition, I examine whether high debt (a serious problem in many Latin American countries), accumulated just prior to, or at the beginning of, the shocks, contributed to the growth collapse (Rodrik rejected this hypothesis for his entire sample). The variable, DEBTAV7277, is external debt as a percentage of GDP averaged over 1972-1977 (data from Global Development Finance and World Development Indicators). Latitude and distance from the equator are often used in growth regressions to capture both cultural (e.g., institutions) and/or environmental (e.g., the tropic's specific challenges for growth) impacts (see, for example, Bloom and Sachs, 1998 and Hall and Jones, 1999). I include both a measure of north-south distance, LATITUDE (degrees latitude converted to decimals), and distance from the equator, DISTEQUAT (the absolute value of latitude).

Table 4, Column 1 displays the impact of including the TRADESHOCK variable.

Terms of trade shocks seem to have a great impact in explaining the growth collapse in Latin America since the $\mathrm{R}^{2}$ of the regression increased to 0.87 from 0.28 without this variable. 
(Adding TRADESHOCK meant Barbados and Suriname were dropped from the original Latin America sample.) In addition, the inclusion of TRADESHOCK caused both openness to trade (although implying greater trade led to lower growth) and initial (1975) youth dependency (at the 90 percent level) to become significant. Also, a dummy variable for the dependence of oil exports (equal to one for Trinidad and Tobago and Venezuela) was significant. Table 4, Column 2 indicates that debt burden had nothing to do with the growth collapse (again, confirming Rodrik's result). Given the insignificance of DEBTAV7277 (tstatistic of 0.02), the fact that initial GDP per capita and government institutions became significant is probably the result of excluding Puerto Rico from the data set.

Table 4

North-south distance, or latitude, is significant (as shown in Table 4, Column 3). Indeed, the inclusion of this variable caused government institutions and ethnic fractionalization (at the 90 percent level) to become significant, and initial youth dependency (significant in Column 1) and openness to trade (which previously had a counter-intuitive, negative sign) to be insignificant. Moreover, the explanatory power of the regression was increased $\left(\mathrm{R}^{2}\right.$ rose to 0.92$)$. However, distance from the equator, interestingly, is not significant (see Table 4, Column 4) at a standard level (t-statistic is 1.3). The fact that latitude, but not distance from the equator, is significant and negative, implies that the specific geography of the Western Hemisphere is important, but environment (e.g., proximity to the tropics) is not. Since the continents in the Western Hemisphere have major axes that run North-to-South, countries tend to be similar according to latitude (as opposed to Eurasia, where countries of similar latitudes vary greatly).

Further evidence that latitude captures important similarities and differences among these countries in ways more popular measures do not was that variables for the percent of population speaking English, percent speaking any European language, percent Catholic, and 
dummy variables for islands and English legal origin were all insignificant (results not shown). A dummy variable for the tropics (one for a country with a latitude between plus/minus 23 degrees), was significant (not shown). However, this tropics variable only distinguishes the southern cone countries (Argentina, Chile, Paraguay, and Uruguay), something latitude obviously does as well. Moreover, the sign for tropics and latitude coefficient implied the same relationship with growth. Not only is the growth experience of Latin American and Caribbean countries different from the rest of the world, their experience can be further separated regionally. The importance of US, British, or Spanish influence, as well as the strength of indigenous cultures, to some degree, vary latitudinally, and thus, this influence may be more accurately captured by latitude than with dummy variables or shares of a specific population.

\subsection{Demographic influences revisited}

The African, Mediterranean, and Asian countries are the ones for which demography was significant in explaining growth instability. For these countries, unlike for Latin American and Caribbean countries, TRADESHOCK (as well as TRADEOPEN) was not important in explaining the economic growth instability-TRADESHOCK had a t-statistic of 0.27 (result not shown). In the next regressions, I decompose the dependency effect by the growth of the individual populations. Particularly, I use POP014CHANGE7590, defined as the growth rate of the 14-years and under population over the 1975 to 1990 period, POP1564CHANGE7590, defined as the growth rate of the working-age population, and POP65UPCHANGE7590, defined as the growth rate of the retired population. To specifically capture the impact of changes in infant mortality on the growth of the young population, I also add a term for the average percentage change in infant mortality over 1977-1982, INFANTMORTCHANGE7782. 
Table 5, Column 1 shows that youth dependency's impact on growth stability was driven by the negative impact of an increase in the young population, rather than a positive impact of an increase in working-age population, since the coefficient for this second factor is not statistically significant. (Likewise, the change in retired population was not significantly different from zero.) The explicit inclusion of the change in the young population meant that the level of youth dependency is not at all statistically significant, that the dummy variable for sub-Saharan Africa (usually negative and significant in growth regressions) is also not at all statistically significant, and that the dummy variable for primary exports is now only marginally significant (at or just below the 90 percent level).

Table 5, Column 2 indicates that a drop in infant mortality early in the period was correlated with a subsequent increase in economic growth (although not all at a standard level of statistical significance-t-statistic of 0.6). A non-significant (and certainly a non-positive) coefficient for infant mortality change is contrary to the Bloom and Williamson (1998) argument that population growth stemming from a fall in infant mortality should have an immediate negative effect on economic growth. However, given the apparent endogeneaity between economic growth and improvements in infant mortality, the relationship indicated in Table 5, Column 2 is not surprising. Although international aid and other mechanisms of technology transfer have led to a convergence among countries in many health related measures, like, for example, life expectancy (see Wilson, 2001), improvements in infant mortality show a pattern of divergence. For example, in the sample of developing countries I use, the correlation between the level of infant mortality in 1977 and the improvement in infant mortality over 1977-1990 is 0.47 . In other words, a lower level of infant mortality in 1977 is associated with a greater improvement_or more negative change—in infant mortality over the following period; thus, the positive correlation implies divergence. The 
correlation between the level of infant mortality in 1977 and GDP per capita in 1975 is -0.7, i.e., higher GDP is associated with lower infant mortality, again suggesting divergence.

The most surprising result of the regressions shown in Table 5 is that the change in the working-age population is insignificant. The recent population and economic growth literature argues that working-age cohorts are the part of the population whose growth contributes to economic growth. One possible explanation for this insignificance is that the growth of the working-aged population, although good for economic growth, has little impact on the stability of economic growth. Another possibility is provided by Lindh and Malmberg (1999), who break the working-age cohort down further, and find that for OECD countries young adults (age 15-29) have a negative impact on economic growth, while the 50-64 age group has the strongest positive influence. Thus, I break down the change in the working-age population into the change in the 15-29 age group and the change in the $30-64$ age group. The coefficients for these two new variables (results not shown) were of opposite signs (coefficient for the 15-29 age group was negative) and of similar absolute magnitudes, as the new theory would predict; however, neither coefficient was statistically significant. Perhaps a further break down of the working-age population would find a cohort with a statistically significant positive impact on economic growth stability.

\section{Table 5}

Next, I explore how prior growth in the youth population might be good for economic growth, in light of the surprising result that growth of the working-age population was insignificant, by considering youth population's interaction with human capital. It seems reasonable that if countries with growing young populations invest in education, they would reap benefits later on. To test this theory, I create and apply a number of interaction terms consisting of combinations of 1975 primary and secondary enrollment ratios (data from Barro and Lee) and earlier periods of young (ages 0-14) population change (1965-1975 and 1970- 
1980). None of these interaction terms entered the regressions as statistically significantindeed, they all had t-statistics of one or less (results not shown). One explanation for this disappointing result is none of my interaction terms fully represents the benefit of a growing, more educated population (perhaps, because the dates I use to calculate the terms are not accurately capturing the timing of these effects). Another explanation is data quality-eight countries (from the initial 69) were dropped from the regressions because of lack of enrollment data.

Lastly, I look at how geographic variables (latitude and distance from the equator) may influence the growth collapse for this second group of countries. Not surprisingly, latitude (given the East-West orientation of Eurasia and, to a lesser degree, Africa) was not significant (results not shown). In addition, neither distance from the equator nor a dummy variable for the tropics was significant (results also not shown).

\section{Conclusions}

The paper makes a contribution by combining findings in two related, but until now, rather unconnected literatures. Specifically, I use demographic variables to help explain the instability of economic growth in developing countries, and in doing so, put forth a new hypothesis on how population may impact economic growth. In addition, the paper shows further evidence in defining the growth experience regionally.

Pritchett (2000) demonstrates the necessity of considering economic growth instability—particularly for developing countries. Rodrik (1999) shows that growth instability (or lack of it in the Asian case) is the defining characteristic of the Asian "miracle." Bloom and Williamson (1998) illustrate that the demographic transition (from high to low rates of mortality/fertility) was an important part of the performance of the high-growth Asian countries. This paper pulls these findings together by demonstrating that the demographic transition (or lack of it) is valuable in explaining the stability of economic growth (or lack of 
it) for developing countries, even after accounting for institutional factors and other measures of social division proved relevant by Rodrik (1999). Furthermore, this relationship between growth stability and demographic change holds true for countries other than the high-growth Asian ones. Indeed, adding the change in young population to the instability of growth regressions of Rodrik, led the sub-Saharan Africa and the Asian dummy variables to be statistically insignificant, when in typical growth regressions they are usually negative and significant and positive and significant, respectively.

The importance in these regressions of both government quality and youth dependency for African, Mediterranean, and Asian countries supports Bloom et al.'s (2001) contention that; "The demographic dividend is not, however, automatic. Given the right kind of policy environment, this demographic dividend can help to produce a sustained period of economic growth. ..." Also, combining the finding (discussed earlier in the paper) that economic growth (for whatever reasons) became considerably more difficult beginning in the latter half of the 1970s with this paper's theory of population's impact on weathering economic shocks can help explain what Kelly and Schmidt (1995) call "the new negative correlations." In other words, because the 1960s were a relatively trouble-free time for economic growth, population dependency's importance was not made clear; however, during the more turbulent 1970s and 1980s countries with lower (and falling) dependency burdens weathered the economic shocks better. It appears rates of change, rather than levels, of youth dependency is most important. Furthermore, when youth dependency was separated into its component parts, growth of the young (0-14) population was highly significant (and had the same sign as change in youth dependency), whereas growth of the working-age population was insignificant. However, disappointingly, interaction terms attempting to capture the relationship among human capital (or school enrollment rates), growth in the youth 
population, and economic growth, were all statistically insignificant. Perhaps, more work on the human capital aspect of population change's influence would be rewarding.

It was surprising and a little frustrating that demographic change appeared to have no impact on economic growth stability in Latin American and Caribbean countries (indeed, only the trade shock variable matters much for this group). Neither levels of nor change in youth dependency was significant for Latin American and Caribbean countries, a result that was robust regardless whether the regressions used changes in aggregate youth dependency or the individual population (i.e., aged 0-14 or 15-65, or even 15-29 or 30-65) growth rates. It was hoped that the greater break down of working-age cohorts might capture the fact that the demographic transition typically occurred at a slower rate in Latin America than in Asia. It is not very satisfying to say a group of countries as large as Latin America and the Caribbean are just different. However, Brock and Durlauf (2001) argue that growth correlates should not be expected to have the same effect on such complex heterogeneous objects as countries, and Block (2001) finds that Africa grows differently. Yet, interesting was the paper's finding that the experience of Western Hemisphere countries can be separated further according to latitude—an important proxy, it was argued, for cultural, historical, and institutional similarities in this part of the world. 


\section{References}

Barlow, Robin. 1994. "Population Growth and Economic Growth: Some More Correlations." Population and Development Review 20, 1: 153-165.

Ben-David, Dan and David H. Papell. 1998. "Slowdowns and Meltdowns: Postwar Growth Evidence from Seventy-four Countries," The Review of Economics and Statistics, 80 (4): 561-571.

Block, Steven A. 2001. "Does Africa grow differently?” Journal of Development Economics, 65: 443-467.

Bloom and Freeman. 1988. "Economic development and the timing of components of population growth" Journal of Policy Modeling. 10(1):57-81.

Bloom, David E. and Jeffrey D. Sachs. 1998. "Geography, Demography, and Economic Growth in Africa." Brookings Papers on Economic Activity.

Bloom, David E. and Jeffrey G. Williamson. 1998. "Demographic Transitions and Economic Miracles in Emerging Asia.” The World Bank Economic Review, 12, 3: 419-455.

Bloom, David E., David Canning, and Jaypee Sevilla. 2001. "Economic Growth and the Demographic Transition.” NBER Working Paper 8685.

Brander and Dowrick. 1994. "The role of fertility and population in economic growth: empirical results from aggregate cross-national data. Journal of Population Economics. 7(1):1-25.

Brock, William A. and Steven N. Durlauf. 2001. "Growth Empirics and Reality," The World Bank Economic Review, 15 (2): 229-272.

Crenshaw EM, Ameen AZ, Christenson M. 1997. "Population dynamics and economic development: Agespecific population growth rates and economic growth in developing countries, 1965 to 1990" American Sociological Review 62 (6): 974-984.

Easterly, William, Michael Kremer, Lant Pritchett, and Lawrence H. Summers. 1993. "Good Policy or Good Luck: Country Growth Performance and Temporary Shocks," Journal of Monetary Economics 32: 459-483.

Easterly, William and Ross Levine. 1997. “Africa's Growth Tragedy: Policies and Ethnic Divisions.” The Quarterly Journal of Economics : 1203-1249.

Easterly, William and Aart Kraay 1999. "Small States, Small Problems?" World Bank Policy Research Department Working Paper No. 2139

Easterly, William and Aart Kraay. 2000. "Small States, Small Problems?" World Development, 28(11): 20132027.

Easterly, William. 2001. “The Lost Decades: Developing Countries' Stagnation in Spite of Policy Reform 19801998," Journal of Economic Growth, 6: 135-157.

Hall and Jones. 1999. "Why do some countries produce so much more output per worker than others?" Quarterly Journal of Econometrics. 14(1):83-116.

Kaufmann, Daniel, Aart Kraay and Pablo Zoido-Lobaton 1999. "Governance Matters". World Bank Policy Research Department Working Paper No. 2196.

Kelley, Allen C. and Robert M. Schmidt. 1995. "Aggregate Population and Economic Growth Correlations: The Role of the Components of Demographic Change,” Demography, 32, 4: 543-555.

Kelley, Allen C. and Robert M. Schmidt. 2001. "Economic and Demographic Change: A Synthesis of Models, Findings, and Perspectives." in Population Matters: Demographic Change, Economic Growth, and Poverty in the Developing World. Nancy Birdsall, Allen C. Kelley, and Steven W. Sinding editors. Oxford: Oxford University Press. pp. 67-105. 
Kenny, Charles. 1999."Why aren’t countries rich?" Journal of Development Studies. 35(5):26-47.

Lindh, Thomas and Bo Malmberg. 1999. “Age structure effects and growth in the OECD, 1950-1990,” Journal of Population Economics, 12: 431-449.

Mauro, Paolo. 1995. “Corruption and Growth,” The Quarterly Journal of Economics, 110, 3: 681-712.

Pritchett, Lant. 2000. "Understanding Patterns of Economic Growth: Searching for Hills among Plateaus, Mountains, and Plains," The World Bank Economic Review, 14, 2:221-250.

Rodrik, Dani. 1999. "Where Did All the Growth Go? External Shocks, Social Conflict, and Growth Collapses," Journal of Economic Growth, 4: 385-412.

Talyor, Charles Lewis and Michael C. Hudson. 1972. World Handbook of Political and Social Indicators. 2 d ed. New Haven: Yale University Press.

Wilson, Chris. 2001. “On the Scale of Global Demographic Convergence 1950-2000.” Population and Development Review 27 (1): 155-171. 
Table 1. Dependent Variable: Per Capita GDP Growth 1975-1992 Minus Developing Country Sample Average Per-Capita GDP Growth 1975-1992

\begin{tabular}{lcc}
\hline Variable & Coefficient & Std. Error \\
\hline C & $15.17^{\star}$ & 3.01 \\
SSA & $-1.20^{\star \star}$ & 0.61 \\
LAC & $-1.83^{*}$ & 0.59 \\
ASIA & 0.79 & 0.72 \\
LNGDP75 & $-1.42^{\star}$ & 0.31 \\
DIFAVG6075 & 0.101 & 0.096 \\
ETHINCFRAC & $-2.35^{\star}$ & 0.80 \\
QUALTGOV9801 & $1.37^{\star}$ & 0.34 \\
YDEP75 & $-3.49^{\star \star}$ & 1.49 \\
YOUTHDEPCHANGE & $-0.54^{\star \star}$ & 0.25 \\
& & \\
$\mathrm{~N}$ & 94 & \\
Adj. $\mathrm{R}^{2}$ & 0.62 & \\
\hline
\end{tabular}

Notes: Standard Errors are White consistent. Levels of statistical significance indicated by asterisks: * 99 percent, $* * 95$ percent, $* * * 90$ percent.

Table 2. Dependent Variable: Per Capita GDP Growth 1975-1992 Minus Per-Capita GDP Growth 1960-1975

\begin{tabular}{|c|c|c|c|c|}
\hline & & & \multicolumn{2}{|c|}{2} \\
\hline Variable & Coefficient & Std. Error & Coefficient & Std. Error \\
\hline $\bar{C}$ & $15.58^{*}$ & 2.97 & $16.76^{*}$ & 2.98 \\
\hline SSA & $-1.20^{\star *}$ & 0.61 & -1.00 & 0.74 \\
\hline LAC & $-1.83^{*}$ & 0.59 & $-1.53^{*}$ & 0.61 \\
\hline ASIA & 0.79 & 0.72 & 0.85 & 0.75 \\
\hline LNGDP75 & $-1.42^{*}$ & 0.31 & $-1.61^{*}$ & 0.33 \\
\hline GDPGROWTH6075 & $-0.90^{*}$ & 0.096 & $-0.89^{*}$ & 0.11 \\
\hline ETHINCFRAC & $-2.35^{*}$ & 0.80 & $-2.48^{*}$ & 0.89 \\
\hline QUALTGOV9801 & $1.38^{*}$ & 0.34 & $1.37^{*}$ & 0.40 \\
\hline YDEP75 & $-3.49^{* *}$ & 1.49 & $-3.09^{* *}$ & 1.49 \\
\hline YOUTHDEPCHANGE & $-0.54^{\star *}$ & 0.25 & $-0.51^{* *}$ & 0.24 \\
\hline TRADEOPEN & & & -0.00011 & 0.0047 \\
\hline EXPORTOIL & & & 0.74 & 0.62 \\
\hline EXPORTPRIM & & & $-0.83^{* *}$ & 0.43 \\
\hline $\mathrm{N}$ & 94 & & 93 & \\
\hline Adj. $R^{2}$ & 0.70 & & 0.71 & \\
\hline
\end{tabular}

Notes: Standard Errors are White consistent. Levels of statistical significance indicated by asterisks: * 99 percent, $* * 95$ percent, $* * * 90$ percent. 
Table 3. Dependent Variable: Per Capita GDP Growth 1975-1992 Minus Per-Capita GDP Growth 1960-1975. Sample split between Latin American and Caribbean countries and all other countries.

\begin{tabular}{|c|c|c|c|c|}
\hline \multirow[b]{2}{*}{ Variable } & \multicolumn{2}{|c|}{ All other countries } & \multicolumn{2}{|c|}{ Latin Amer. \& Carib. } \\
\hline & Coefficient & Std. Error & Coefficient & Std. Error \\
\hline C & $17.42^{*}$ & 3.26 & 14.89 & 13.68 \\
\hline SSA & -0.96 & 0.73 & & \\
\hline ASIA & 0.69 & 0.67 & & \\
\hline LNGDP75 & $-1.82^{*}$ & 0.36 & -1.32 & 1.45 \\
\hline GDPGROWTH6075 & $-0.89^{*}$ & 0.12 & $-1.07^{*}$ & 0.33 \\
\hline ETHINCFRAC & $-2.61^{*}$ & 0.82 & -0.24 & 2.45 \\
\hline QUALTGOV9801 & $1.40^{*}$ & 0.45 & 1.11 & 1.28 \\
\hline YDEP75 & -2.28 & 1.82 & -3.92 & 5.91 \\
\hline YOUTHDEPCHANGE & $-0.64^{*}$ & 0.20 & -0.50 & 0.75 \\
\hline TRADEOPEN & 0.004 & 0.006 & -0.02 & 0.02 \\
\hline EXPORTOIL & 0.87 & 0.76 & 0.23 & 1.82 \\
\hline EXPORTPRIM & $-0.97^{\star \star}$ & 0.49 & -1.37 & 1.32 \\
\hline $\mathrm{N}$ & 68 & & 25 & \\
\hline Adj. $R^{2}$ & 0.78 & & 0.28 & \\
\hline
\end{tabular}

Notes: Standard Errors are White consistent. Levels of statistical significance indicated by asterisks: *99 percent, $* * 95$ percent, $* * * 90$ percent.

Table 4. Dependent Variable: Per Capita GDP Growth 1975-1992 Minus Per-Capita GDP Growth 1960-1975. Sample includes only Latin American and Caribbean countries.

\begin{tabular}{|c|c|c|c|c|c|c|c|c|}
\hline \multirow[b]{2}{*}{ Variable } & \multicolumn{2}{|c|}{1} & \multicolumn{2}{|c|}{2} & \multicolumn{2}{|c|}{3} & \multicolumn{2}{|c|}{4} \\
\hline & Coeff. & $\begin{array}{c}\text { Std. } \\
\text { Error }\end{array}$ & Coeff. & $\begin{array}{l}\text { Std. } \\
\text { Error }\end{array}$ & Coeff. & $\begin{array}{l}\text { Std. } \\
\text { Error }\end{array}$ & Coeff. & $\begin{array}{l}\text { Std. } \\
\text { Error }\end{array}$ \\
\hline C & $17.74^{\star \star}$ & 6.86 & $20.56^{*}$ & 6.38 & 7.29 & 5.13 & $16.54^{\star *}$ & 6.26 \\
\hline GDPGROWTH6075 & $-0.87^{*}$ & 0.22 & $-1.03^{*}$ & 0.23 & $-0.98^{*}$ & 0.19 & $-0.78^{*}$ & 0.23 \\
\hline LNGDP75 & -1.20 & 0.79 & $-1.70^{\star *}$ & 0.74 & -0.51 & 0.62 & -1.33 & 0.82 \\
\hline EXPORTPRIM & 0.33 & 0.61 & 0.085 & 0.80 & -0.78 & 0.44 & 0.024 & 0.46 \\
\hline EXPORTOIL & $3.62^{*}$ & 1.12 & $3.78^{*}$ & 0.95 & $3.43^{*}$ & 0.86 & $4.05^{\star}$ & 1.22 \\
\hline YDEP75 & $-4.47^{\star \star \star}$ & 2.38 & -2.87 & 2.41 & 2.65 & 2.53 & -3.30 & 2.01 \\
\hline YOUTHDEPCHANGE & -0.30 & 0.24 & -0.53 & 0.32 & 0.19 & 0.15 & -0.32 & 0.23 \\
\hline ETHINCFRAC & -1.64 & 1.14 & -0.72 & 1.22 & $-1.52^{* * *}$ & 0.84 & -0.95 & 1.02 \\
\hline TRADEOPEN & $-0.016^{\star *}$ & 0.0071 & $-0.032^{* *}$ & 0.012 & 0.0058 & 0.0084 & -0.013 & 0.0073 \\
\hline QUALTGOV9801 & 0.92 & 0.60 & $1.26^{\star * *}$ & 0.58 & $0.93^{* *}$ & 0.39 & 0.79 & 0.54 \\
\hline TRADESHOCK & $-102.81^{*}$ & 14.16 & $-86.57^{*}$ & 15.52 & $-113.70^{*}$ & 13.84 & $-102.00^{*}$ & 13.20 \\
\hline DEBTAV7277 & & & 0.00038 & 0.020 & & & & \\
\hline LATITUDE & & & & & $-0.058^{*}$ & 0.014 & & \\
\hline DISTEQUAT & & & & & & & 0.047 & 0.037 \\
\hline $\mathrm{N}$ & 23 & & 22 & & 23 & & 23 & \\
\hline Adj. $R^{2}$ & 0.87 & & 0.89 & & 0.92 & & 0.87 & \\
\hline
\end{tabular}

Notes: Standard Errors are White consistent. Levels of statistical significance indicated by asterisks: * 99 percent, $* * 95$ percent, $* * * 90$ percent. 
Table 5. Dependent Variable: Per Capita GDP Growth 1975-1992 Minus Per-Capita GDP Growth 1960-1975. Sample does not include Latin American and Caribbean countries.

\begin{tabular}{lcccc}
\hline & \multicolumn{2}{c}{1} & & \multicolumn{2}{c}{2} \\
\hline Variable & Coefficient & Std. Error & Coefficient & Std. Error \\
\hline C & & & & \\
SSA & $17.54^{*}$ & 3.07 & $18.05^{*}$ & 3.15 \\
ASIA & -0.55 & 0.68 & -0.50 & 0.69 \\
LNGDP75 & 1.00 & 0.67 & 1.03 & 0.67 \\
GDPGROWTH6075 & $-1.80^{*}$ & 0.34 & $-1.89^{*}$ & 0.37 \\
ETHINCFRAC & $-0.81^{*}$ & 0.13 & $-0.80^{*}$ & 0.14 \\
QUALTGOV9801 & $-2.79^{*}$ & 0.79 & $-2.82^{*}$ & 0.79 \\
YDEP75 & $1.59^{*}$ & 0.45 & $1.60^{*}$ & 0.44 \\
POP014CHANGE7590 & -0.88 & 1.83 & -0.97 & 1.83 \\
POP1564CHANGE7590 & $-0.68^{*}$ & 0.19 & $-0.65^{*}$ & 0.20 \\
POP65UPCHANGE7590 & 0.21 & 0.41 & 0.18 & 0.42 \\
EXPORTOIL & -0.12 & 0.18 & -0.12 & 0.18 \\
EXPORTPRIM & 0.92 & 0.84 & 0.99 & 0.85 \\
INFANTMORTCHANGE7782 & $-0.84^{* * *}$ & 0.51 & -0.83 & 0.51 \\
& & & -0.064 & 0.11 \\
N & 69 & & & \\
Adj. $R^{2}$ & 0.79 & & 69 & \\
\hline
\end{tabular}

Notes: Standard Errors are White consistent. Levels of statistical significance indicated by asterisks: * 99 percent, ** 95 percent, $* * * 90$ percent.

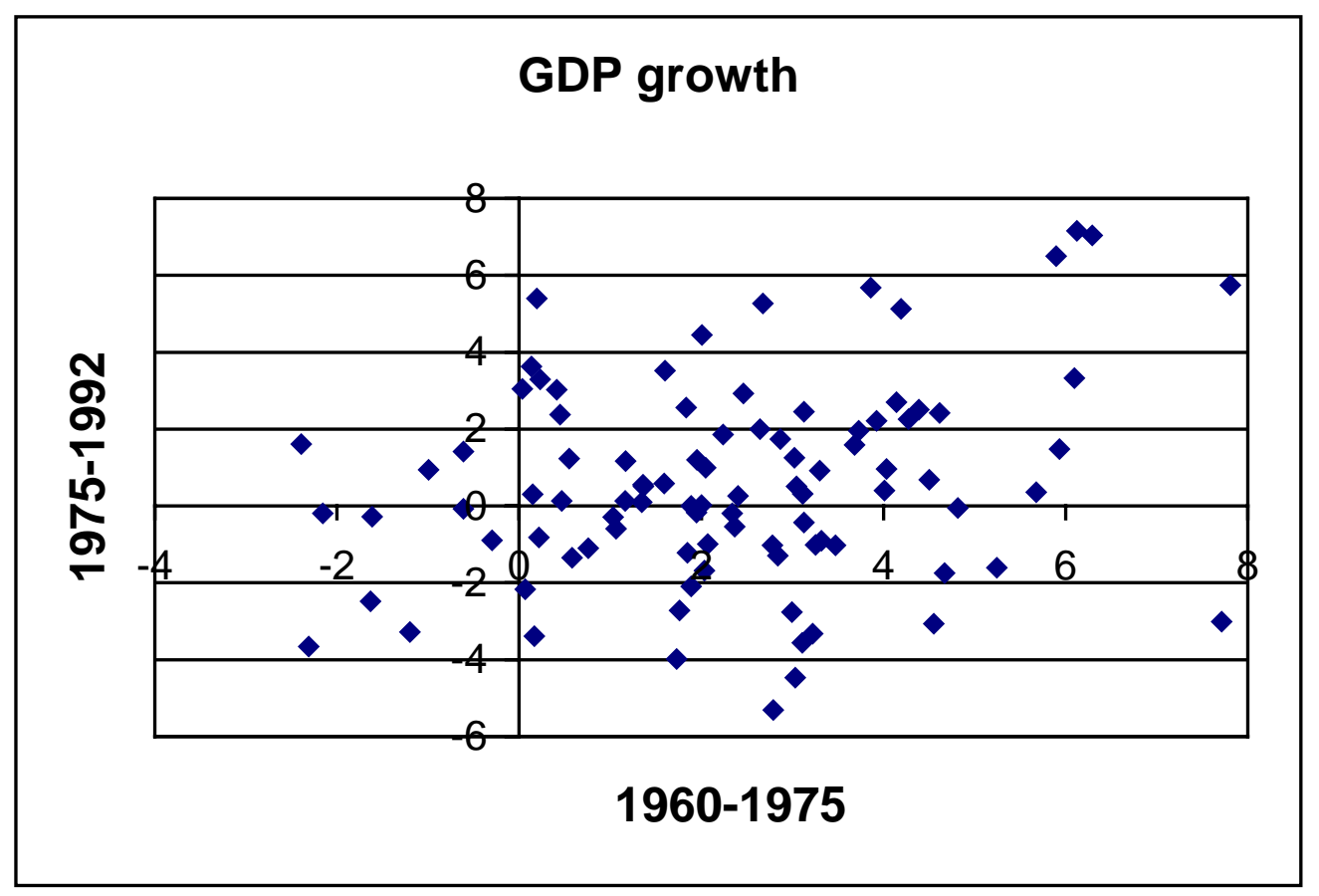

Figure 1: The relationship between average, yearly per-capita GDP growth over the periods 1960-1975 and 1975-1992 for a sample of 94 developing countries. 


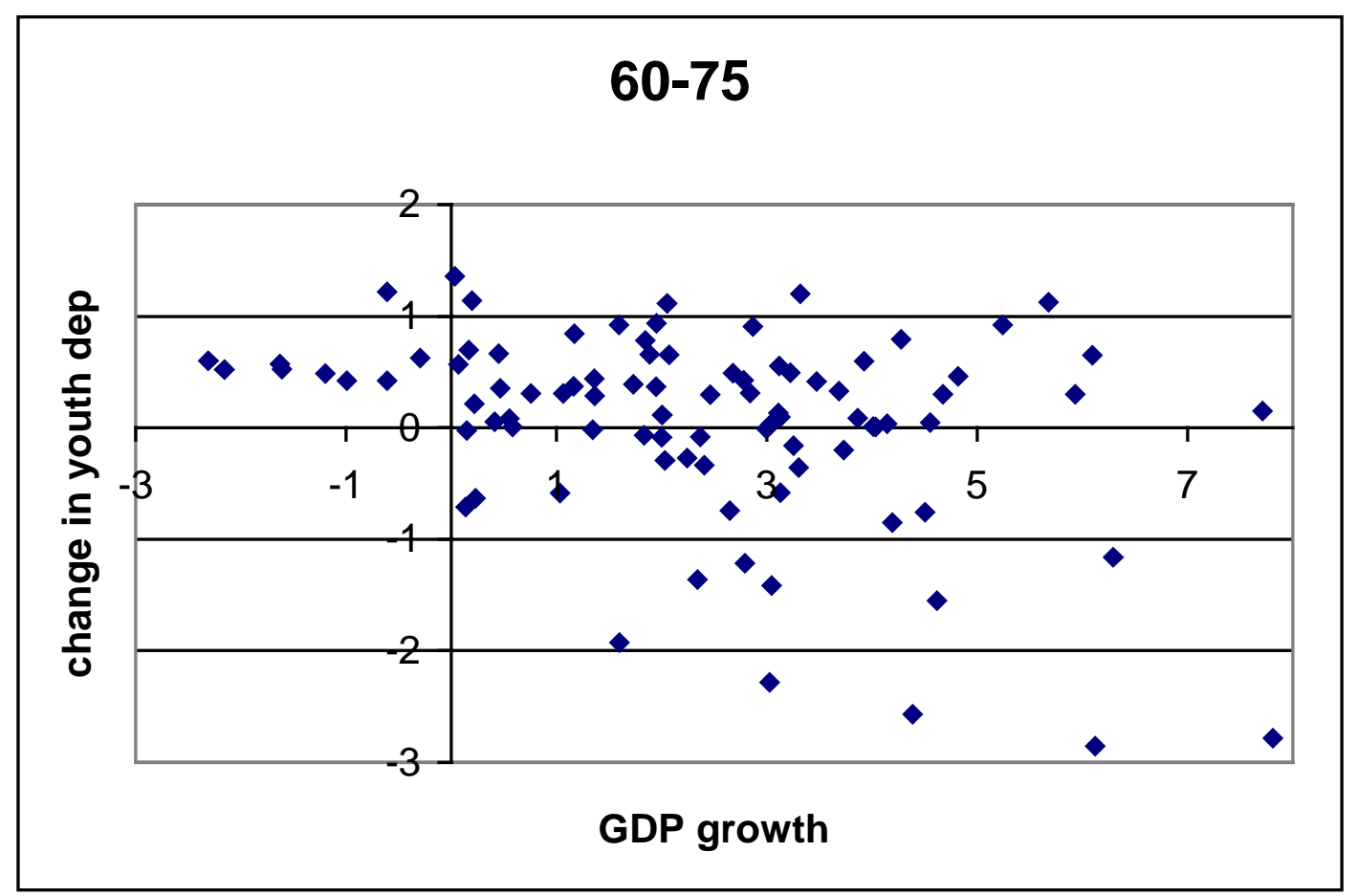

Figure 2: The relationship between average, yearly per-capita GDP growth over 1960-1975 and average, yearly change in the youth dependency ratio (the population ages 0-14 over population 15-64) over the same period for the same 94 developing countries shown in Figure 1.

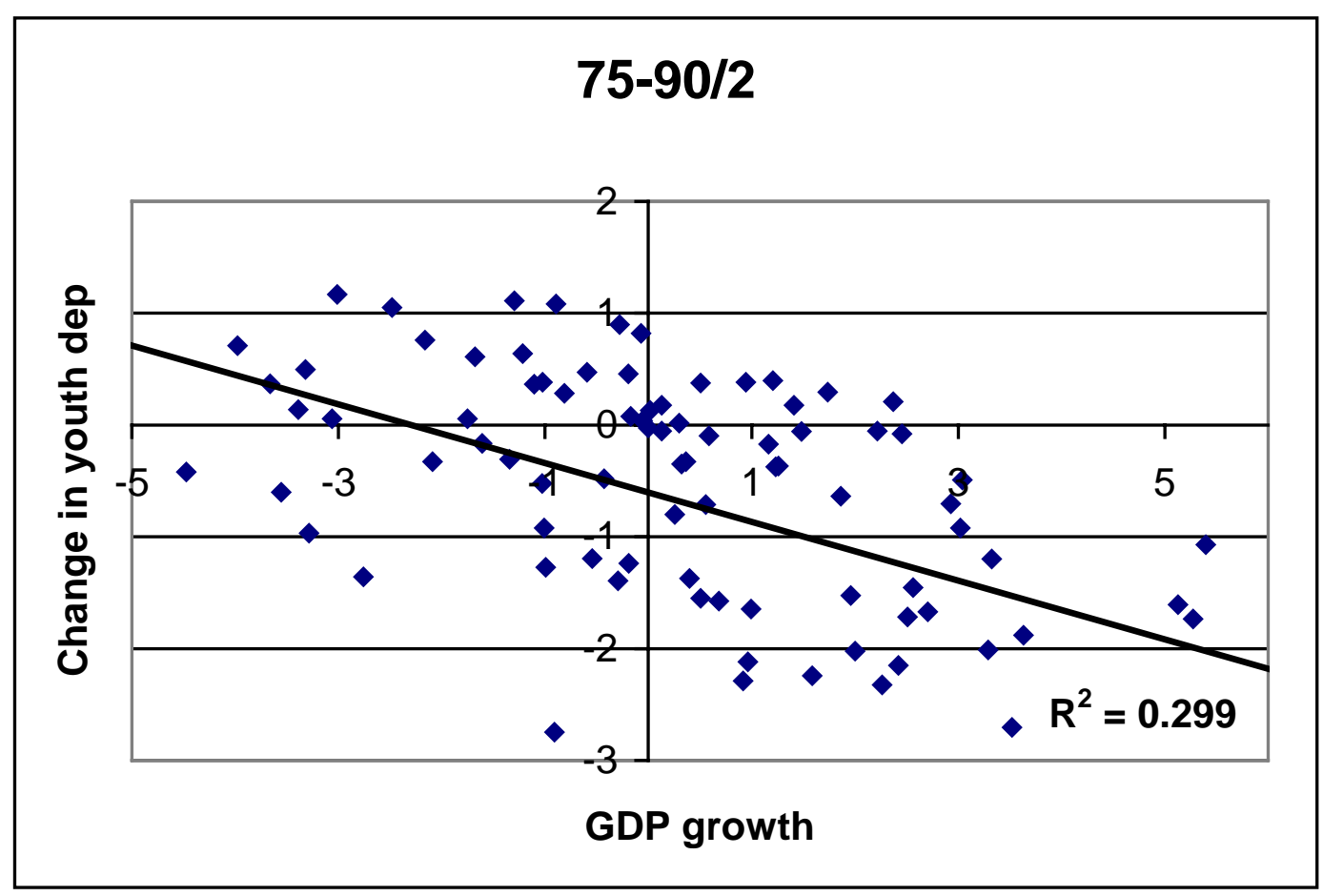

Figure 3: The relationship between average, yearly per-capita GDP growth over 1975-1992 and average, yearly change in the youth dependency ratio over 1975-1990 for the same 94 developing countries shown in Figures 1 and 2 . 


\section{Appendix}

Countries used in study with most recent year of GDP per capita data (if not 1992)

\begin{tabular}{|c|c|c|c|c|c|}
\hline ALGERIA & & GUINEA & & NIGERIA & \\
\hline ANGOLA & 1989 & GUINEA-BISSAU & 1990 & PAKISTAN & \\
\hline ARGENTINA & 1990 & GUYANA & 1989 & PANAMA & \\
\hline BANGLADESH & & HAITI & & $\begin{array}{l}\text { PAPUA NEW } \\
\text { GUINEA }\end{array}$ & \\
\hline BARBADOS & 1989 & HONDURAS & & PARAGUAY & \\
\hline BENIN & 1990 & HONG KONG & & PERU & \\
\hline BOLIVIA & & INDIA & & PHILIPPINES & \\
\hline BOTSWANA & 1989 & INDONESIA & & PUERTO RICO & 1989 \\
\hline BRAZIL & & IRAN & 1987 & RWANDA & \\
\hline BURKINA FASO & & IRAQ & & SENEGAL & 1990 \\
\hline BURUNDI & & JAMAICA & 1990 & SIERRA LEONE & \\
\hline CAMEROON & & JORDAN & 1990 & SINGAPORE & \\
\hline CAPE VERDE & & KENYA & & SOMALIA & 1989 \\
\hline $\begin{array}{l}\text { CENTRAL AFRICAN } \\
\text { REPUBLIC }\end{array}$ & & $\begin{array}{l}\text { KOREA, REPUBLIC } \\
\text { OF }\end{array}$ & 1990 & SOUTH AFRICA & \\
\hline CHAD & & LESOTHO & & SRI LANKA & \\
\hline CHILE & & LIBERIA & 1986 & SURINAME & 1990 \\
\hline CHINA & & MADAGASCAR & & SWAZILAND & 1989 \\
\hline COLOMBIA & & MALAWI & & $\begin{array}{l}\text { SYRIAN ARAB } \\
\text { REPUBLIC }\end{array}$ & 1989 \\
\hline CONGO & & MALAYSIA & & TAIWAN, CHINA & 1990 \\
\hline COSTA RICA & & MALI & & TANZANIA & 1990 \\
\hline COTE D'IVOIRE & & MALTA & 1989 & THAILAND & 1988 \\
\hline CYPRUS & & MAURITANIA & & TOGO & \\
\hline $\begin{array}{l}\text { DOMINICAN } \\
\text { REPUBLIC }\end{array}$ & & MAURITIUS & & $\begin{array}{l}\text { TRINIDAD AND } \\
\text { TOBAGO }\end{array}$ & \\
\hline ECUADOR & & MEXICO & & TUNISIA & 1990 \\
\hline EGYPT & & MOROCCO & & TURKEY & \\
\hline EL SALVADOR & 1986 & MOZAMBIQUE & & UGANDA & \\
\hline ETHIOPIA & 1990 & MYANMAR & 1989 & URUGUAY & \\
\hline FIJI & & NAMIBIA & & VENEZUELA & \\
\hline GABON & 1990 & NEPAL & 1986 & $\begin{array}{l}\text { ZAIRE (Congo, } \\
\text { Dem. Rep.) }\end{array}$ & 1989 \\
\hline GAMBIA, THE & & NICARAGUA & 1990 & ZAMBIA & 1989 \\
\hline GHANA & & NIGER & 1989 & ZIMBABWE & 1990 \\
\hline GUATEMALA & & & & & \\
\hline
\end{tabular}

